\title{
Anxiety and Sleep Quality Levels of Emergency Medical Personnel and Factors Affecting Them During the Coronavirus Disease-2019 Pandemic
}

\section{COVID-19 Pandemisinde Acil Servis Çalıșanlarının Anksiyete ve Uyku Kalitesi Düzeyleri ve Etkileyen Faktörlerin Belirlenmesi}

\author{
(D) Dilek Şayık, (D) Ayfer Açıkgöz* , (D) Şeyhmus Kaya** \\ Eskişehir City Hospital, Clinic of Education, Eskişehir, Turkey \\ * Eskişehir Osmangazi University Faculty of Health Sciences, Department of Pediatric Nursing, Eskişehir, Turkey \\ **Eskişehir City Hospital, Clinic of Adult Emergency Service, Eskişehir, Turkey
}

\begin{abstract}
Objective: The study was conducted to determine the anxiety and sleep quality levels of emergency medical service personnel as well as factors affecting them during the Coronavirus disease-2019 (COVID-19) pandemic.

Materials and Methods: This descriptive study included 247 medical professionals working in emergency medical services.

Results: The mean age of the medical personnel was $32.62 \pm 7.36$ years, of whom $54.3 \%$ were females, $49.8 \%$ were married, $89.9 \%$ were university graduates and $47.8 \%$ nurse. Of the medical staff, $21.9 \%$ had mild anxiety, $15.8 \%$ had moderate anxiety, and $33.2 \%$ had high anxiety. Pittsburgh sleep quality index scores of all participants were $>5$. A strong and positive relationship $(p<0.001)$ was found between the anxiety level (19.24 \pm 15.67$)$ and sleep quality (14.39 \pm 3.13$)$ of participants. The study revealed that healthcare personnel who worked 24 hour shifts, smoked and/or drank alcohol, had a psychological disorder, and lacked adequate protective equipment had high anxiety scores and poor sleep quality. Moreover, healthcare professionals who experienced problems with childcare, thought that working conditions affect their children negatively, and were afraid of COVID-19 transmission to themselves and their families had high anxiety scores and poor sleep quality.

Conclusion: During the pandemic, monitoring the emergency medical personnels' health and work is important to determine their levels of anxiety and sleep quality and to provide necessary psychological support.
\end{abstract}

Keywords: Emergency medical services, anxiety, COVID-19 pandemic, medical personnel, sleep quality
Öz

Amaç: Bu çalışma, Koronavirüs hastalığı-2019 (COVID-19) pandemi döneminde acil servis çalışanlarının anksiyete ve uyku kalitesi düzeyleri ile etkileyen faktörleri belirlemek amacıyla yapılmıştır.

Gereç ve Yöntem: Tanımlayıcı tipte olan bu araştırma acil servislerde çalışan 247 sağlık personeli ile yapılmıştır.

Bulgular: Yaş ortalamaları 32,62 $\pm 7,36$ olan sağlık personellerinin \%54,3'ü ( $n=134)$ kadın, \%49,8'i (n=123) evli, \%89,9'u ( $n=222)$ üniversite mezunu ve $\% 47,8^{\prime} i(n=118)$ hemşire idi. Sağlık personelinin $\% 21,9^{\prime}$ u hafif, $\% 15,8$ 'i orta ve $\% 33,2^{\prime}$ si yüksek anksiyete düzeyine sahipti. Katılımcıların tamamının Pittsburgh uyku kalitesi indeks puanı 5 'in üzerinde idi. Katılımcıların anksiyete düzeyi $(19,24 \pm 15,67)$ ile uyku kalitesi $(14,39 \pm 3,13)$ arasında kuvvetli ve pozitif yönde ilişki saptandı. Çalışmada; 24 saatlik vardiyalar halinde çalışan, sigara ve/veya alkol kullanan, psikolojik bir hastalığı olan ve yeterli koruyucu ekipmana sahip olmadığını belirten sağıı personellerinin anksiyete puanlarının yüksek, uyku kalitelerinin kötü olduğu saptandı. Ek olarak, çocuklarının bakımı ile ilgili sorun yaşayan, çalışma şartlarının çocuklarını olumsuz etkilediğini düşünen, kendisine ve ailesine COVID-19 bulaşmasından korkan sağlık personellerinin anksiyete puanları yüksek, uyku kaliteleri kötü idi.

Sonuç: Pandemi döneminde sağlık personellerinin çalışma şeklinin yeniden gözden geçirilmesi, anksiyete ve uyku kalitelerinin belirlenerek gerekli psikolojik desteğin sağlanması önemlidir.

Anahtar Kelimeler: Acil servis, anksiyete, COVID-19 pandemisi, sağlık personeli, uyku kalitesi 


\section{Introduction}

Pandemics are unpredictable situations that can negatively affect people $(1,2)$, these effects are physical, social and psychological (3). The occupational group that is thought to be most affected from the pandemic is medical personnel $(2,4-9)$, while the institutions most impacted are hospitals. During a pandemic, all the normal functions of hospitals, and especially of the emergency medical services, areaffected (3). The Coronavirus disease-2019 (COVID-19) pandemic, whose effects are still on going, has been a case in point. Emergency medical services are often the first point of contact for individuals who present with symptoms of COVID-19. As COVID-19 spreads and mortality rates grow, so the work load, and physical and psychological fatigue of those working in the emergency medical services also increases. There remains, however, a profound need for medical personnel in order to combat the pandemic, and it is necessary that they are both protected and able to carry out their duties. The physical and psychological health of these individuals should be closely monitored and any problems identified should be solved quickly and at an early stage (10).

During the pandemic, anxiety and deterioration in sleep quality have been among the most common negative consequences experienced by medical personnel (5-7). Healthcare personnel who work in the front line and have to work in close contact with individuals diagnosed with COVID-19 may have higher state and trait anxiety levels and health concerns (9). It should be kept in mind that sleep problems that increase with anxiety can lead to deepening psychological disorders (11). Since the problem-solving skills of medical personnel who experience anxiety and sleep disorders are negatively affected, their quality of life may also deteriorate severely (12). This may reduce their motivation to carry out their professional responsibilities (13). It is important that the sleep quality and anxiety levels of medical personnel remain within acceptable limits so that adequate medical services can continue to be provided. During the pandemic only, no study could be found focusing only on those working in emergency medical services in the literature. There is also no study examining the effect of the status of having problems with childcare during the pandemic period and the status of being affected by the pandemic in terms of their communication with their children on the anxiety and sleep quality of healthcare personnel.

This study was carried out to determine the anxiety and sleep quality levels of adult and/or pediatric emergency service personnel and the factors affecting them during the COVID-19 pandemic.

\section{Materials and Methods}

\section{Type of Research}

This was a descriptive, cross-sectional study.

\section{Place and Duration of the Study}

The research was carried out in Turkey via the survey method between 21 August and 21 September 2020. In the period of the study, the number of people diagnosed with COVID-19 in
Turkey varied between 1204 and 1742. Mortality rates ranged between 18 and 65 per day.

\section{Sampling}

In the study, there was no sample selection and questionnaires were sent to the entire universe. The research was completed with 247 medical staff who agreed to participate, who were working in the adult and/or pediatric emergency services, and who met the inclusion criterion. This criterion; Being 18 years old or older, working in the emergency services in Turkey, accepting to participate in the study, giving informed consent, answering all the questions in the questionaire completely.

\section{Data Collection Tools}

The data were collected using the descriptive information form, the Beck anxiety scale, and the Pittsburg sleep quality index (PSQI).

Introductory information form: This form was prepared by the researchers in line with the literature (4-7). The form contains questions to determine the socio-demographic and occupational characteristics of the medical personnel and their working conditions during the COVID-19 outbreak.

The Beck anxiety scale: This scale was developed by Beck et al. (14). Cronbach's Alpha coefficient is 0.93. The scale was adapted to Turkish by Ulusoy et al. (15) and the scale consists of 21 questions which aim to measure the severity of an individual's anxiety, and is a four-point Likert-type scale. The level of anxiety is "mild" if the total score from the scale is between 8 and 15 points, "moderate" if it is between 16 and 25 points, and "high" if it is between 26 and 63 points.

PSQI: The PSQI was developed Buysse et al. (16) to evaluate sleep quality and sleep disturbances experienced by individuals in the previous month. The PSQI was adapted to Turkish by Agargun et al. (17) and the Cronbach Alpha coefficient was found to be 0.80 . The PSQI consists of 24 questions and the total score ranges from 0 and 21. Each question is scored between 0-3. A total score greater than 5 indicates "poor sleep quality".

\section{Data Collection}

The data were collected online via WhatsApp using the survey method. The questionnaire was shared in the Whatsapp groups in which there were chief physicians of all emergency services in Turkey $(n=1514)$. Chief physicians were asked to share this questionnaire with all of the healthcare personnel in their departments.

\section{Ethical Aspect of the Research}

Before beginning the research, the necessary permission was obtained from the Ministry of Health (dated 11.06.20 and numbered 2020-06-06T11_00_45), as well as from the ethics committee permission (dated 14.08.2020 and numbered E-25403353-050.99-77351). The study was carried out with voluntary participants.

\section{Statistical Analysis}

Data are expressed as n, percentage, average, standard deviation, and minimum and maximum values. The Shapiro- 
Wilk test was used to test the compliance of the data to normal distribution. The Mann-Whitney $\mathrm{U}$ and Kruskal-Wallis $\mathrm{H}$ tests were applied to data sets that were not normally distributed and consisted of independent variables. The Spearman and Pearson Correlation tests were applied to non-normally distributed data sets to determine the relationships and directions between variables. Analyses were performed using the IBM SPSS 21.0 (IBM Corporation, Armonk NY, USA) program. $\mathrm{P}<0.05$ was considered statistically significant in the study.

\section{Results}

The ages of the participants ranged from 20 to 62 and their average age was $32.62 \pm 7.36 .54 .3 \%$ of the participants $(n=134)$ were female, $49.8 \%(n=123)$ were married, $89.9 \%$ $(n=222)$ were university graduates, 95.1\% $(n=235)$ lived in nuclear families, $44.1 \%(n=109)$ had children and the income of $57.9 \%(n=143)$ was found to be equal to their expenditure (Table 1). Table 1 includes the sociodemographic characteristics of the participants.

In Table 2 and 3, shows a comparison of some characteristics of the medical personnel and their PSQI and Beck anxiety scores. It was determined that the personnel who smoked, drank alcohol and had psychological diseases had poor sleep quality (Table 2) and high anxiety scores (Table 3 ).

In Table 4 and 5, shows a comparison of some characteristics of the medical personnel related to their work and COVID-19 and their PSQI and Beck anxiety scores. In the study, the healthcare personnel working in 24-hour shifts, being afraid of being infected with COVID-19, thinking they needed psychological support and having inadequate protective equipment, had poor sleep quality (Table 4) and high anxiety scores (Table 5). The healthcare personnel who had problems with childcare and who thought that working conditions negatively affected their children, also had poor sleep quality (Table 4) and high anxiety scores (Table 5). The healthcare professionals working more than 46 hours a week and only in the pediatric emergency care services, had worse sleep quality (Table 4).

The average Beck anxiety score of the participants in the study was $19.24 \pm 15.67 .21 .9 \%(n=54)$ of the medical staff had mild anxiety, $15.8 \%(n=39)$ of them had moderate anxiety, and $33.2 \%(n=82)$ of them had high anxiety. The mean PSQI score of the participants was $14.39 \pm 3.13$. All the PSQI scores of the participants $(n=247,100 \%)$ were greater than 5 . There was a strong and positive correlation $(r=0.586 ; p<0.001)$ between the medical personnel's mean Beck anxiety scores and their mean PSQI scores.

\section{Discussion}

\section{Comparison of the Participants' Characteristics and PSQI Scores}

The present study determined that the sleep quality of the participants diagnosed with a chronic disease and/or psychological illness was worse than that of the other personnel. Similar to the results of this study, other studies found that the sleep quality of medical personnel with chronic (18-20) or psychological disorders $(18,21)$ had deteriorated. It is known that coronavirus has a more severe course in individuals with chronic diseases and that mortality rates are higher in these individuals. The poor sleep quality of medical personnel with chronic illnesses may be related to this situation. It was an expected result that the sleep quality of individuals with a

\begin{tabular}{|c|c|c|c|}
\hline \multicolumn{2}{|l|}{ Variables } & $\mathbf{n}$ & $\%$ \\
\hline \multirow{4}{*}{ Age distribution } & 20-29 years & 113 & 45.7 \\
\hline & $30-39$ years & 83 & 33.6 \\
\hline & 40-49 years & 48 & 19.4 \\
\hline & 50 years and above & 3 & 1.2 \\
\hline \multirow{2}{*}{ Gender } & Female & 134 & 54.3 \\
\hline & Male & 113 & 45.7 \\
\hline \multirow{3}{*}{ Marital status } & Married & 123 & 49.8 \\
\hline & Single & 111 & 44.9 \\
\hline & Divorced & 13 & 5.3 \\
\hline \multirow{4}{*}{$\begin{array}{l}\text { Educational } \\
\text { status }\end{array}$} & High school & 25 & 10.1 \\
\hline & Associate degree & 33 & 13.4 \\
\hline & Bachelor's degree & 118 & 47.8 \\
\hline & Master or above & 71 & 28.7 \\
\hline \multirow{2}{*}{ Family structure } & Nuclear family & 235 & 95.1 \\
\hline & Extended family & 12 & 4.9 \\
\hline \multirow{2}{*}{$\begin{array}{l}\text { The status of } \\
\text { having children }\end{array}$} & Childless & 138 & 55.9 \\
\hline & Having a child or children & 109 & 44.1 \\
\hline \multirow{3}{*}{ Income level } & Income<expenses & 46 & 18.6 \\
\hline & Income=expenses & 143 & 57.9 \\
\hline & Income>expenses & 58 & 23.5 \\
\hline \multirow{4}{*}{ Occupation } & Physician/specialist physician & 79 & 32.0 \\
\hline & Nurse & 118 & 47.8 \\
\hline & $\begin{array}{l}\text { First aid and eemergency care } \\
\text { technician }\end{array}$ & 31 & 12.6 \\
\hline & Medical secretary & 19 & 7.7 \\
\hline \multirow{3}{*}{$\begin{array}{l}\text { Years in the } \\
\text { profession }\end{array}$} & $<1$ year & 33 & 13.4 \\
\hline & Between 2-9 years & 99 & 40.1 \\
\hline & 10 years or above & 115 & 46.6 \\
\hline \multirow{7}{*}{$\begin{array}{l}\text { The region of } \\
\text { Turkey in which } \\
\text { the participants } \\
\text { worked }\end{array}$} & Central Anatolia & 149 & 60.3 \\
\hline & Marmara & 64 & 25.9 \\
\hline & Aegean & 9 & 3.6 \\
\hline & Mediterranean & 3 & 1.2 \\
\hline & Black Sea & 4 & 1.6 \\
\hline & South East Anatolia & 14 & 5.7 \\
\hline & East Anatolia & 4 & 1.6 \\
\hline \multirow{5}{*}{$\begin{array}{l}\text { The hospital } \\
\text { where the } \\
\text { participant is } \\
\text { working now }\end{array}$} & City hospital & 114 & 46.2 \\
\hline & Public hospital & 75 & 30.4 \\
\hline & University hospital & 23 & 9.3 \\
\hline & Training and research hospital & 31 & 12.6 \\
\hline & Private hospital & 4 & 1.6 \\
\hline
\end{tabular}




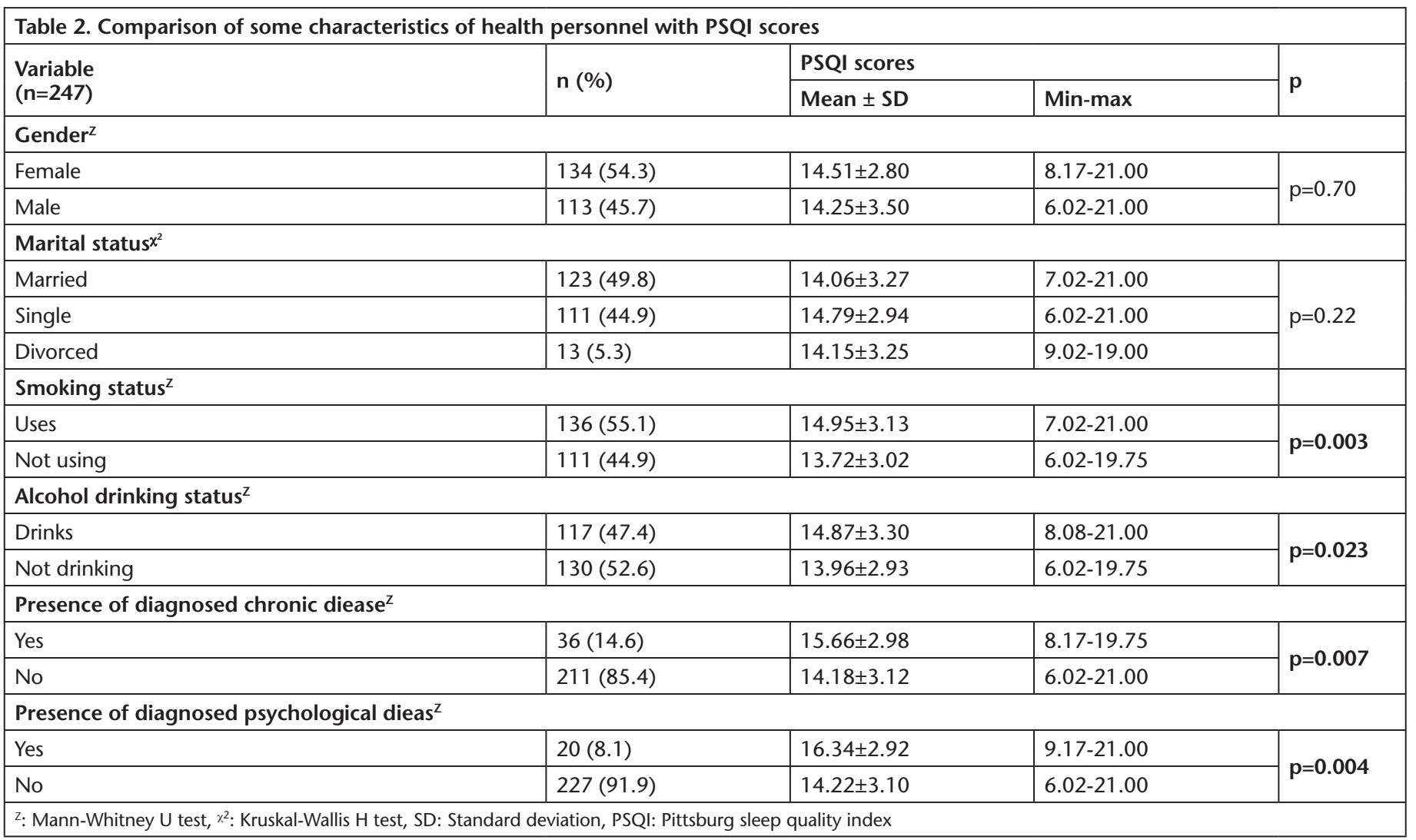

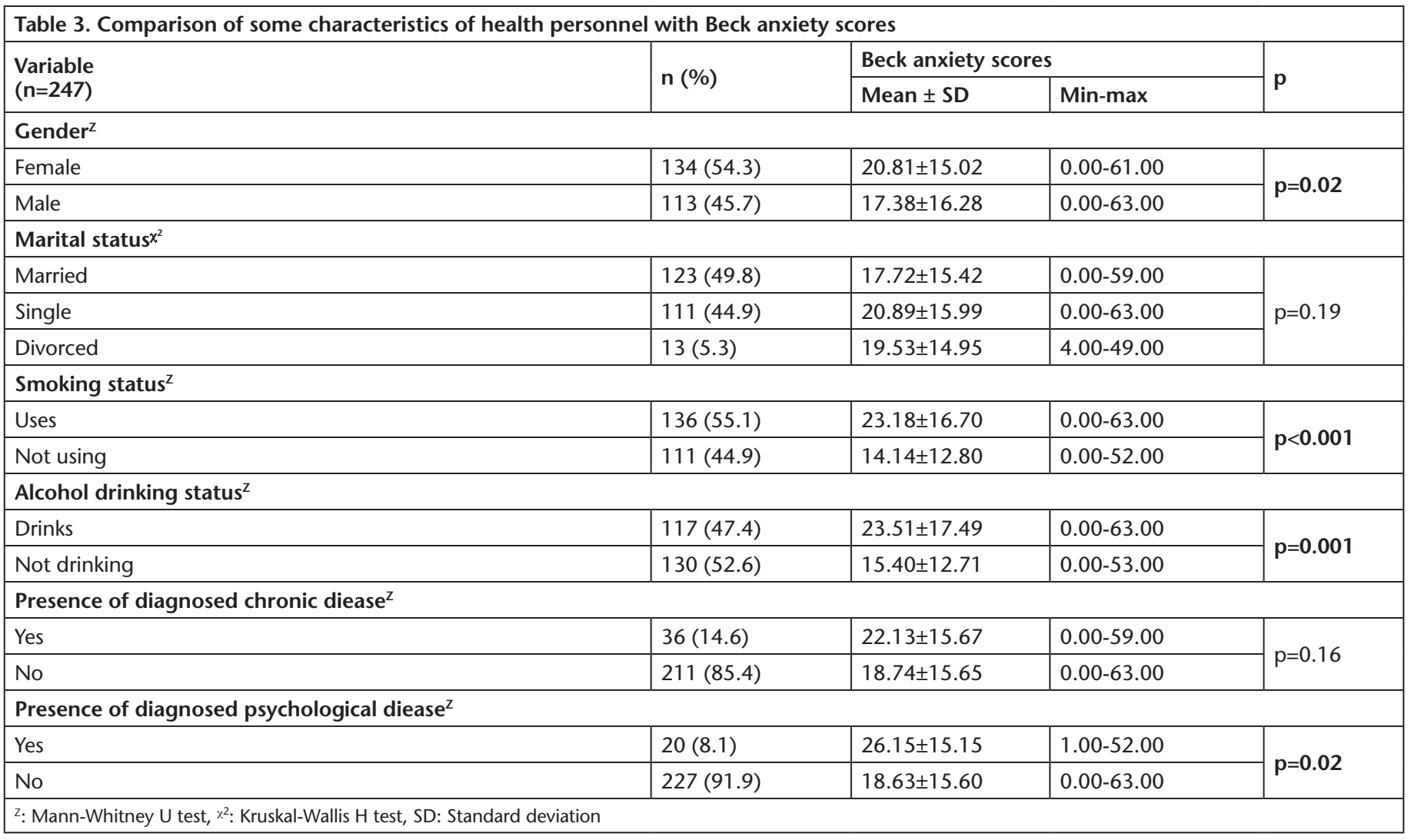


diagnosed psychological disorder would be negatively affected during the pandemic, given that even individuals who have not previously experienced any psychological problems may develop symptoms of these $(11,22)$.

The study determined that the sleep quality of cigarette smokers and alcohol drinkers was worse than that of others. Studies have shown that of those who smoke cigarettes $(20,23-25)$ and drink alcohol $(20,24,25)$ have a lower sleep quality than those who do not. The results of this study and other studies are important in terms of showing that the sleep quality in cigarette smokers and alcohol drinkers is also disturbed and that these people should receive psychological support.

The study determined that the sleep quality of medical personnel working in pediatric emergency clinics was worse

\begin{tabular}{|c|c|c|c|c|}
\hline \multirow{2}{*}{$\begin{array}{l}\text { Variable } \\
(n=247)\end{array}$} & \multirow{2}{*}{ n (\%) } & \multicolumn{2}{|l|}{ PSQI scores } & \multirow{2}{*}{$p$} \\
\hline & & Mean \pm SD & Min-max & \\
\hline \multicolumn{5}{|l|}{ Title $^{x^{2}}$} \\
\hline Doctor & $79(32.0)$ & $14.48 \pm 3.28$ & $8.17-19.75$ & \multirow{3}{*}{$p=0.87$} \\
\hline Nurse & $118(47.8)$ & $14.29 \pm 3.10$ & $6.02-21.00$ & \\
\hline First and emergency aid technician & $31(12.6)$ & $14.71 \pm 3.10$ & $8.17-19.33$ & \\
\hline \multicolumn{5}{|l|}{ Working year in the profession $x^{2}$} \\
\hline$\leq 1$ year & $33(13.4)$ & $14.67 \pm 3.57$ & $6.02-21.00$ & \multirow{3}{*}{$p=0.62$} \\
\hline $2 \leq$ years $\leq 9$ & $99(40.1)$ & $14.58 \pm 2.89$ & $8.17-19.75$ & \\
\hline$\geq 10$ years & $115(46.6)$ & $14.15 \pm 3.21$ & $4.02-21.00$ & \\
\hline \multicolumn{5}{|l|}{ Emergency department $x^{2}$} \\
\hline \multicolumn{5}{|l|}{ Working style for the last 1 month $\mathrm{x}^{2}$} \\
\hline Daytime shift & $33(13.4)$ & $13.20 \pm 2.13$ & $8.17-17.50$ & \multirow{3}{*}{$p=0.002$} \\
\hline Day and night shifts & $97(39.3)$ & $14.11 \pm 2.90$ & $8.17-19.75$ & \\
\hline 24 hour shift & $117(47.4)$ & $14.96 \pm 3.44$ & $6.02-21.00$ & \\
\hline \multicolumn{5}{|l|}{ Working hours per week ${ }^{\mathrm{z}}$} \\
\hline$\leq 45$ hours & $92(37.2)$ & $13.76 \pm 3.21$ & $6.02-21.00$ & \multirow{2}{*}{$p=0.01$} \\
\hline$\geq 46$ hours & $155(62.8)$ & $14.77 \pm 3.04$ & $8.17-19.75$ & \\
\hline \multicolumn{5}{|c|}{ Fear of infection with the COVID-19 virus ${ }^{\mathrm{Z}}$} \\
\hline Yes & $213(86.2)$ & $14.61 \pm 3.04$ & $6.02-21.00$ & $p=0.009$ \\
\hline No & $109(44.1)$ & $13.20 \pm 2.99$ & $8.02-19.67$ & $p<0.001$ \\
\hline \multicolumn{5}{|c|}{ The state of thinking that he/she has adequate personal protective equipment while working ${ }^{z}$} \\
\hline Yes & $177(71.7)$ & $13.87 \pm 2.99$ & $7.02-21.00$ & \multirow{2}{*}{$p<0.001$} \\
\hline No & $70(28.3)$ & $15.71 \pm 3.12$ & $6.02-19.75$ & \\
\hline \multicolumn{5}{|c|}{ Those with children $(n=109,44.1 \%)$; having problem/problems with their children's care in the last weeks ${ }^{z}$} \\
\hline Yes & $61(55.9)$ & $15.36 \pm 2.86$ & $7.02-21.00$ & \multirow{2}{*}{$\mathrm{p}<0.001$} \\
\hline No & $48(44.1)$ & $12.32 \pm 2.91$ & $7.50-19.00$ & \\
\hline \multicolumn{5}{|c|}{ Those with children $(n=109,44.1 \%)$; Thinking that working conditions in the last weeks negatively affect their children ${ }^{z}$} \\
\hline Yes & $83(76.1)$ & $14.82 \pm 3.05$ & $7.50-21.00$ & \multirow{2}{*}{$p<0.001$} \\
\hline No & $26(23.9)$ & $11.46 \pm 2.46$ & $7.02-16.50$ & \\
\hline
\end{tabular}


than that of those working in adult emergency and adult + child emergency clinics. There is no research finding on this subject in the relevant literature. Providing care and treatment for sick children can be highly emotionally demanding for medical personnel. The result obtained in the current study can be associated with this situation.
It was found that the sleep quality of participants working 24 hours a day and whose working hours were more than 45 hours per week was worse than the others. The sleep quality of emergency service personnel $(20,26,27)$ and intensive care personnel (28) was affected negatively due to the increase in their working hours in the studies before the pandemic.

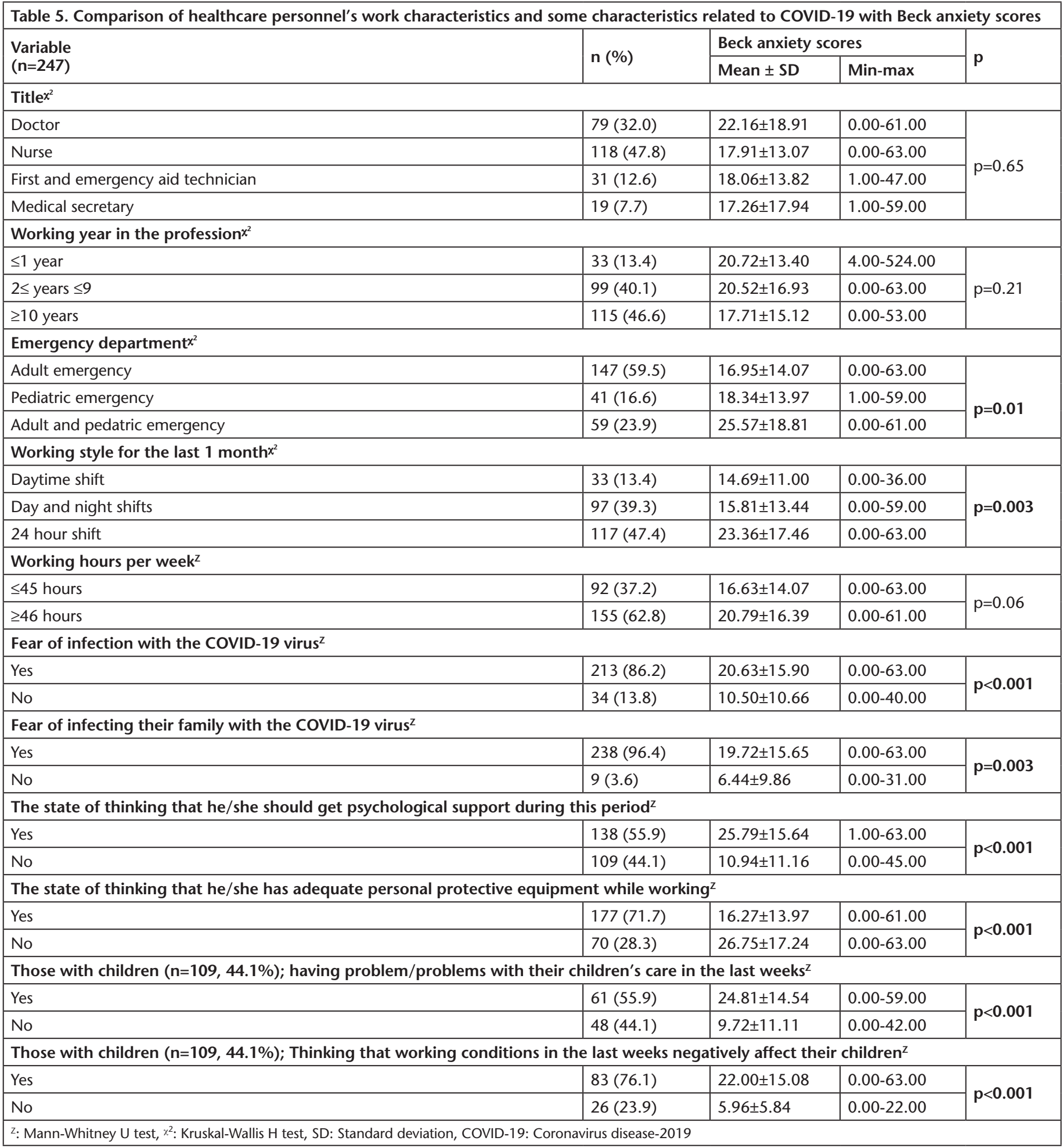


Similarly, during the pandemic a positive relationship can be seen between the increase in the working hours of medical personnel (4), working night shifts (5), an increase in workload (21) and poor sleep quality. This result shows the importance, where possible, of offering staff shorter shifts, limiting their working hours and ensuring that weekly working hours do not exceed 45 hours.

The study determined that the sleep quality of medical personnel who stated that they were afraid of catching COVID19, who thought that they needed psychological support, and who did not have sufficient personal protective equipment, was worse than others. One study (5), stated that medical personnel who believed that their personal protective equipment was insufficient had poor sleep quality. Another study (29) reported that healthcare professionals treating infected patients during the COVID-19 pandemic had aggravated anxiety and sleep quality and needed more psychological support. Xiao et al. (1) stated that providing social support during the COVID19 pandemic not only reduces anxiety symptoms, but also indirectly improves sleep quality. In the literature, another study comparing individuals's with the thought of the need for psychological support and sleep quality could not be found. These results are substantial in terms of showing that when adequate protective equipment and thenecessary psychological support is provided to medical personnel during the pandemic, then their sleep quality will subsequently improve.

It was found that the sleep quality of personnel who had problems related to caring for their children in the previous weeks, and who thought that their working conditions negatively affected their children was worse than others. No other study comparing these characteristics and sleep quality could not have been found in the literature. During the pandemic, the workload of medical personnel has increased. At the same time, medical personnel have experienced social stigmatization as possible carriers of infection. During the pandemic, personnel in the health care sector may have experienced difficulties in caring for their children due to childcare centers, nurseries, kindergartens and schools being closed, or limited in when they can open, and may also have problems finding babysitters (30). In the face of all these negative events, it is to be expected that medical personnel would experience physical and psychological problems and that their sleep quality would be disturbed.

\section{Comparison of the Participants' Characteristics and Beck Anxiety Scores}

In the study, it was determined that female participants experienced more anxiety. Some of the relevants studies found that female healthcare personnel experience more anxiety during the pandemic (31-36) while other relevants found no relationship between gender and anxiety levels $(4,9,12,21,37)$. In conclusion, it can be suggested that the pandemic affects women more psychologically in general.

The study determined that the anxiety levels of the participants who stated that they had a diagnosis of psychological illness were higher than those of individuals who did not. Similar results have also been found in other studies $(21,38)$. It is important that medical personnel with psychological illnesses be better supported during the pandemic.

It was found that smokers and alcohol drinkers had higher levels of anxiety than those who did not drink or smoke. The increase in the use of cigarettes and alcohol by the participants during the pandemic period was not looked at in the study. This result is similar to the result of Tran et al.'s (39) study. Sallie et al. (40) stated that individuals whose alcohol drinking increased during the pandemic period had higher anxiety levels than other individuals. This shows the importance of monitoring anxiety in medical personnel who smoke cigarettes and drink alcohol.

The study determined that the anxiety levels of medical personnel working in adult + pediatric emergency clinics were higher than those working in adult emergency or pediatric emergency clinics. In the literature review $(32,33,35,37)$, no difference was found between the units where the medical personnel were working during the pandemic and their anxiety levels. The current study is considered that the anxiety of medical personnel increased due to having to provide simultaneous treatment and care to both adults and children, who are very different from each other in terms of their characteristics and needs.

No significant difference was found between the weekly working hours of the participants and their anxiety levels; however, it was found that the anxiety of the participants with more working 24 hours was higher (30). It has been stated in the literature that there is a positive correlation between increase in workload of medical personnel during the pandemic period (12,21), working night shifts (5), an increasein weekly working hours (41) and increased levels of anxiety. Working longer hours increases the time spent with the patient and medical personnel have to wear personal protective equipment for long periods of time (10). Spending more time in thehospital can lead to medical personnel becoming both physically and psychologically exhausted (28). It is thus important that 24-hour shifts and having to be continuously on call be limited as far as possible.

The study found that the anxiety levels of medical personnel who stated that they were afraid of being infected with COVID-19 and of infecting their family with COVID-19, who believed they needed psychological support, and who did not have sufficient protective equipment, were higher than those of other participants. It has been determined that those individuals and medical personnel who think most about COVID-19 experience greater anxiety $(6,21,31,42,43)$. Focusing on the illness over a long period of time increases anxiety. Being with people who are COVID-19 positive can lead to various mental problems $(8,9,35)$. Bai et al. (5) determined that personnel diagnosed with COVID-19 had insufficient personal protective equipment and this situation increases their anxiety. In a study conducted in Turkey, it was observed that there was no difference between access to personal protective equipment and the anxiety scores of nurses working in pandemic hospitals (33). This was because almost all of the participants (98\%) stated that they had 
access to protective equipment (33). It can be said that having access to personal protective equipment during the pandemic affects anxiety greatly. In addition, the vast majority of medical personnel are afraid of infecting their family with COVID-19 and so experience more anxiety $(12,29,31,33,35,36,41)$. During this difficult and tiring period, the fact that medical personnel have to continue to work while also fulfilling all their normal responsibilities at home is another factor that increases anxiety.

The study determined that personnel who had had problems with the care of their children in the previous weeks, and who believed that their working conditions affected their children negatively, had higher anxiety levels than other participants. Due to the increased workload in hospitals during the pandemic, the ways in which medical personnel work have changed, and, as a result, they have not been able to devote time to their families and children. On top of all these negative conditions, the closure of nurseries, kindergartens, and schools for extended periods of time has increased problems regarding the care of their children (30). The fact that babysitters do not want to take care of the children of health care personnel, in order to prevent themselves from becoming infected, may cause anxiety and leave medical professional feeling helpless.

\section{Relationship Between PSQI and Beck Anxiety Scores}

The average PSQI score of the participants in the study was found to be $14.39 \pm 3.13$. All of the participants $(n=247,100 \%)$ had a PSQI score greater than 5; that is, their sleep quality was poor. In the studies conducted before the pandemic period $(20,44-47)$, it was stated that sleep quality was poor in more than half of the healthcare personnel. Studies conducted during the pandemic have found that the mean PSQI score of medical personnel working in clinics ranged from $5.1 \pm 3.8$ to $9.3 \pm 3.8(1,4,12,37,48-50)$. The mean PSQI score of medical personnel working in COVID-19 units has been stated to vary between $8.3 \pm 4.5$ and $16.0 \pm 3.7$, while the score of those not working in COVID-19 units varies between $5.2 \pm 3.7$ and $4 \pm 3.13$ $(4,29,50,51)$. As a result of the current study, the PSQI scores of the participants were found to be higher than in all other studies. This can be explained by the fact that the first place where individuals with severe COVID-19 symptoms are brought is usually the emergency clinic, that very fast and systematic care is usually required, and that this situation causes stress and severely disrupts the sleep quality of personnel. The increase in the workload of the emergency room personnel may be another reason for their diminished sleep quality.

The average Beck anxiety score of the participants was found to be $19.24 \pm 15.67 .21 .9 \%$ of the medical personnel had mild anxiety, $15.8 \%$ of them had moderate anxiety, and $33.2 \%$ of them had high anxiety. In other recent studies conducted during the pandemic, the average Beck anxiety score of medical personnel working in clinics ranges from $7.7 \pm 8.7$ to $16.5 \pm 13.6(12,48,52)$. Studies have shown that, of medical personnel working in pandemic clinics, between $23.9 \%$ and $38.0 \%$ have mild anxiety, between $17.3 \%$ and $20.0 \%$ have moderate anxiety, and between $13.0 \%$ and $27.2 \%$ have high anxiety $(12,52)$. In a study conducted in Şanlıurfa it was found that $53.7 \%$ of emergency room personnel had mild, $28.4 \%$ moderate, and $17.9 \%$ severe anxiety (31). In line with these results, it can be said that medical personnel working in emergency departments during the pandemic have a higher rate of moderate and severe anxiety than those working in clinical services. This may be due to the high risk in emergency clinics of direct contact with COVID-19 patients who have not yet been diagnosed.

Similar to this study, a number of studies have found a positive significant relationship between anxiety and sleep quality $(1,4,5,49)$. This result is significant as it shows that attempts to reduce medical personnel's anxiety levels will also improve their sleep quality.

\section{Study Limitations}

The study has some limitations. Although the researchers sent the questionnaires to all emergency services in Turkey, only volunteer participants filled out questionnaires. Individuals with deteriorated anxiety and sleep quality may have been more willing to fill out the questionnaires.

It is not possible to suggest a definite causal relationship between some characteristics of healthcare professionals and their anxiety and sleep quality levels during the COVID-19 pandemic since this is a cross-sectional study. The absence of a control group makes it difficult to determine whether the factors triggering anxiety and sleep disorders in the general population have triggered anxiety and sleep disturbance in healthcare staff during the pandemic.

The researchers did not know the anxiety and sleep quality levels of the participants in the pre-pandemic period. It is also impossible to review all the rapidly growing literature on the subject as the number of studies on the COVID-19 pandemic and the status of healthcare workers during this pandemic is increasing day by day.

\section{Conclusion}

\section{Comparison of the Participants' Characteristics and PSQI Scores}

Personnel working 24-hour shifts, whose working in pediatric emergency clinics, whose working hours were more than 45 hours per week, who did not have adequate protective equipment, who are experiencing problems with the care of their children, who believe that their working conditions affect their children negatively, and who fear that they will become infected with COVID-19, who thought that they needed psychological support (Table 4), who smoke and/or drink alcohol, who have a psychological illness (Table 2), are the most at-risk groups for poor sleep quality.

\section{Comparison of the Participants' Characteristics and Beck} Anxiety Scores

Personnel working 24-hour shifts, whose working in adult + pediatric emergency clinics, who did not have adequate protective equipment, who are experiencing problems with the care of their children, who believe that their working conditions 
affect their children negatively, and who fear that they or their family will become infected with COVID-19, who thought that they needed psychological support (Table 5), who are female, who smoke and/or drink alcohol, who have a psychological illness (Table 3), are the most at-risk groups for anxiety.

During the pandemic, the anxiety levels of medical personnel working in the emergency services have been high and their sleep quality has been poor. The results of this research show the importance of more closely monitoring the psychological health of the medical personnel whose working especially with pediatric patients in emergency clinics, who are experiencing problems with the care of their children, who believe that their working conditions affect their children negatively, and who have other risks (negative working conditions, smoking and/ or alcohol use, etc.), and providing them with the necessary support.

\section{Relationship Between PSQI and Beck Anxiety Scores}

The study found that as the anxiety levels of medical personnel increased, so their sleep quality also deteriorated. It is recommended that the anxiety and sleep quality of medical personnel be determined and monitored, and that the necessary psychological support be provided.

Acknowledgments: We thank all the medical staff who participated in our study.

\section{Ethics}

Ethics Committee Approval: Before beginning the research, the necessary permission was obtained from the Ministry of Health (dated 11.06.20: and numbered: 2020-06-06T11_00_45), as well as from the ethics committee permission (dated: 14.08.2020 and numbered: E-25403353-050.99-77351).

Informed Consent: The study was carried out with voluntary participants.

Peer-review: Externally and internally peer-reviewed.

\section{Authorship Contributions}

Concept: D.Ş., A.A., Ş.K., Design: D.Ş., A.A., Ş.K., Data Collection or Processing: D.Ş., A.A., Ş.K., Analysis or Interpretation: D.Ş., A.A., Ş.K., Writing: D.Ş., A.A., Ş.K.

Conflict of Interest: No conflict of interest was declared by the authors.

Financial Disclosure: The authors declared that this study received no financial support.

\section{References}

1. Xiao H, Zhang Y, Kong D, Li S, Yang N. The effects of social support on sleep quality of medical staff treating patients with coronavirus disease 2019 (COVID-19) in January and February 2020 in China. Med Sci Monit 2020;26:e923549.

2. Kisely S, Warren N, McMahon L, Dalais C, Henry I, Siskind D. Occurrence, prevention, and management of the psychological effects of emerging virus outbreaks on healthcare workers: rapid review and meta-analysis. BMJ 2020;369:1642.

3. Aciksari K, Kinik K. Process management and outcomes of the emergency department of a training and research hospital in Turkey during the Coronavirus Disease 2019 Pandemic. Anatol Clin 2020;25:263-83.
4. Qi J, Xu J, Li BZ, Huang JS, Yang Y, Zhang ZT, Yao DA, Liu QH, Jia M, Gong DK, Ni XH, Zhang QM, Shang FR, Xiong N, Zhu CL, Wang T, Zhang $X$. The evaluation of sleep disturbances for Chinese frontline medical workers under the outbreak of COVID-19. Sleep Med 2020;72:1-4.

5. Bai $Y$, Wang $X$, Huang $Q$, Wang $H$, Gurarie D, Ndeffo-Mbah M, Fan F, Fu P, Horn MA, Xu S, Mondal A, Jiang X, Zhao H. SARS-CoV-2 infection in health care workers: a retrospective analysis and a model study. MedRxiv 2020.

6. Huang Y, Zhao N. Generalized anxiety disorder, depressive symptoms and sleep quality during COVID-19 outbreak in China: a web-based cross-sectional survey. Psychiatry Res 2020;288:112954.

7. Yuan S, Liao Z, Huang $H$, Jiang B, Zhang $X$, Wang $Y$, Zhao $M$. Comparison of the indicators of psychological stress in the population of Hubei province and non-endemic provinces in China during two weeks during the Coronavirus Disease 2019 (COVID-19) outbreak in February 2020. Med Sci Monit 2020;288:e923767.

8. Kaya B. Effects of pandemic on mental health. Klinik Psikiyatri 2020;23:123-4.

9. Shayganfard M, Mahdavi F, Haghighi M, Sadeghi-Bahmani D, Brand S. Sources of health anxiety for hospital staff working during the Covid-19 Pandemic. Int J Environ Res Public Health 2021;18:3094.

10. Tuncay FE, Koyuncu E, Özel Ş. A review of protective and risk factors affecting psychosocial health of healthcare workers in pandemics. Ankara Med J 2020;20:488-504.

11. Fidancı I, Aksoy H, Yengil Taci D, Fidancı I, Ayhan Başer D, Cankurtaran M. Evaluation of the effect of the COVID 19 Pandemic on sleep disorders and nutrition in children. Int J Clin Pract 202;75:e14170.

12. Korkmaz S, Kazgan A, Cekic S, Tartar AS, Balcı HN, Atmaca M. The anxiety levels, quality of sleep and life and problem-solving skills in healthcare workers employed in COVID-19 services. J Clin Neurosci 2020;80:131-6.

13. Ng SM, Lo HHM, Yeung A, Young D, Fung MHY, Wang AM. Study protocol of brief daily body-mind-spirit practice for sustainable emotional capacity and work engagement for community mental health workers: a multi-site randomized controlled trial. Front Psychol 2020;11:1482.

14. Beck AT, Epstein N, Brown G, Steer RA. An inventory for measuring clinical anxiety: psychometric properties. J Consult Clin Psychol 1988;56:893-7.

15. Ulusoy $M$, Sahin NH, Erkmen H. The Beck anxiety inventory: psychometric properties. J Cognitive Psychotherapy 1998;12:163-72.

16. Buysse DJ, Reynolds CF, Monk TH, Berman SR, Kupfer DJ. The Pittsburgh sleep quality Index: a new instrument for psychiatric practice and research. Psychiatry Res 1989;28:193-213.

17. Agargun MY, Kara H, Anlar O. Validity and reliability of Pittsburgh sleep quality index. Turk J Psychiatry 1996;7:107-11.

18. Cetinol T, Ozvurmaz S. Sleep qualıty and related factors in nurses. Medical Sciences. 2018;13:80-9. https://dergipark.org.tr/en/ download/article-file/549565

19. Lao XQ, Liu X, Deng HB, Chan TC, Ho KF, Wang F, Vermeulen R, Tam T, Wong MCS, Tse LA, Chang LY, Yeoh EK. Sleep quality, sleep duration, and the risk of coronary heart disease: a prospective cohort study with 60,586 adults. J Clin Sleep Med 2018;14:109-17.

20. Patterson PD, Weaver MD, Frank RC, Warner CW, Martin-Gill C, Guyette FX, Fairbanks RJ, Hubble MW, Songer TJ, Callaway CW, Kelsey SF, Hostler D. Association between poor sleep, fatigue, and safety outcomes in emergency medical services providers. Prehosp Emerg Care 2012;16:86-97.

21. Salcan S, Sarıkaya B. The prevalence of anxiety, insomnia and depression among pharmacy employees in the COVID-19 pandemic. Turk J Public Health 2020;18(Suppl):58-65. 
22. Aydınoğlu U, Yazla E. The effect of COVID-19 pandemic on the sleep quality of patients who have the diagnosis of bipolar disorder (tur). I Clinical Psychiatry 2021;24:33-40.

23. Guneser R, Atalay E. Evaluation of sleep quality, work stress and nutritional behavior of ambulance service employees. Journal of PreHospital 2020;5:143-56.

24. Ergun S, Duran S, Gultekin M, Yanar S. Evaluation of the factors which affect the sleep habit and quality of health college students. TJFMPC 2017; 11:186-93.

25. Ilhan Alp S, Deveci M, Erdal B, Akalın RB, Terzi D. Quality of sleep and Insomny violence in university students in the period of COVID-19. Nam Kem Med J 2020;8:295-302.

26. Patterson PD, Suffoletto BP, Kupas DF, Weaver MD, Hostler D. Sleep quality and fatigue among prehospital providers. Prehosp Emerg Care 2010;14:187-93.

27. Patterson PD, Higgins JS, Van Dongen HPA, Buysse DJ, Thackery RW, Kupas DF, Becker DS, Dean BE, Lindbeck GH, Guyette FX, Penner JH, Violanti JM, Lang ES, Martin-Gill C. Evidence-based guidelines for fatigue risk management in emergency medical services. Prehosp Emerg Care 2018;22(Suppl 1):89-101.

28. Donmezdil S, Arac S. Effect of shift work in intensive care on attention disorder in nurses. Int J Clin Pract 2021;75:e13774.

29. Stojanov J, Malobabic M, Stanojevic G, Stevic M, Milosevic V, Stojanov A. Quality of sleep and health-related quality of life among health care professionals treating patients with coronavirus disease-19. Int J Soc Psychiatry 2021;67:175-81.

30. Guvenc R, Baltaci E. COVID-19 and mental health of health workers, COVID-19 pandemic sixth month evaluation report 2020. Turkish Medical Association. 2020;30:349-54. Available from: https://www. ttb.org.tr/kutuphane/covid19-rapor_6/covid19-rapor_6_Part41.pdf

31. Havlioğlu S, Demir HA. Determining the anxiety levels of emergency service employees' working during the COVID-19 Pandemic. Journal of Harran University Medical Faculty 2020;17:251-5.

32. Huang JZ, Han MF, Luo TD, Ren AK, Zhou XP. Mental health survey of medical staff in a tertiary infectious disease hospital for COVID-19. Zhonghua Lao Dong Wei Sheng Zhi Ye Bing Za Zhi 2020;38:192-5.

33. Tercan M, Bozkurt FT, Patmano G, Saraçoğlu G, Gür SC. Anxiety and depression differences between the nurses working at a COVID-19 pandemic hospital. Medical Science and Discovery 2020;7:526-31.

34. Lai J, Ma S, Wang Y, Cai Z, Hu J, Wei N, Wu J, Du H, Chen T, Li R, Tan H, Kang L, Yao L, Huang M, Wang H, Wang G, Liu Z, Hu S. Factors associated with mental health outcomes among health care workers exposed to coronavirus disease 2019. JAMA Netw Open 2020;3:e203976.

35. Uyaroğlu OA, Başaran NÇ, Ozisik L, Karahan S, Tanriover MD, Guven GS, Oz SG. Evaluation of the effect of COVID-19 pandemic on anxiety severity of physicians working in the internal medicine department of a tertiary care hospital: a cross-sectional survey. Intern Med J 2020;50:1350-8.

36. Kuman Tunçel Ö, Taşbakan SE, Gökengin D, Erdem HA, Yamazhan T, Sipahi OR, Pullukçu H, Önen Sertöz Ö, Işıkgöz Taşbakan M. The deep impact of the COVID-19 pandemic on medical students: An online cross sectional study evaluating Turkish students' anxiety. Int J Clin Pract 2021;75:e14139.

37. Zhang R, Hou T, Kong $X$, Wang G, Wang H, Xu S, Xu J, He J, Xiao L, Wang Y, Du J, Huang Y, Su T, Tang Y. Effects of region, epidemic stage, and demographic characteristics on sleep quality and mental disturbances among health care workers during COVID-19 outbreak. Europe PMC. 2020. https://doi.org/10.21203/rs.3.rs-23260/v1.

38. Özdin S, Bayrak Özdin Ş. Levels and predictors of anxiety, depression and health anxiety during COVID-19 pandemic in Turkish society: The importance of gender. Int J Soc Psychiatry 2020;66:504-11.

39. Tran TV, Nguyen HC, Pham LV, Nguyen MH, Nguyen HC, Ha TH, Phan DT, Dao HK, Nguyen PB, Trinh MV, Do TV, Nguyen HQ, Nguyen TTP, Nguyen NPT, Tran CQ, Tran KV, Duong TT, Pham HX, Nguyen LV, Vo TT, Do BN, Duong TH, Pham MK, Pham TTM, Nguyen KT, Yang SH, Chao JC], Duong TV. Impacts and interactions of COVID-19 response involvement, health-related behaviours, health literacy on anxiety, depression and health-related quality of life among healthcare workers: a cross-sectional study. BMJ Open 2020;10:e041394.

40. Sallie SN, Ritou V, Bowden-Jones H, Voon V. Assessing international alcohol consumption patterns during isolation from the COVID-19 pandemic using an online survey: highlighting negative emotionality mechanisms. BMJ Open 2020;10:e044276.

41. Mo Y, Deng L, Zhang L, Lang Q, Liao C, Wang N, Qin M, Huang $\mathrm{H}$. Work stress among Chinese nurses to support Wuhan for fighting against the COVID-19 epidemic. J Nurs Manag 2020;28:1002-9.

42. Bakioğlu F, Korkmaz O, Ercan H. Fear of COVID-19 and Positivity: Mediating Role of Intolerance of Uncertainty, Depression, Anxiety, and Stress. Int J Ment Health Addict 2020:1-14.

43. Gamsızkan Z, Sungur MA, Erdemir G. How do older age, gender and risk groups affect protective behaviours and mental health in the COVID-19 pandemic? Int J Clin Pract 2021;75:e14150.

44. Guyette FX, Morley JL, Weaver MD, Patterson PD, Hostler D. The effect of shift length on fatigue and cognitive performance in air medical providers. Prehosp Emerg Care 2013;17:23-8.

45. Kolo ES, Ahmed AO, Hamisu A, Ajiya A, Akhiwu BI. Sleep health of healthcare workers in Kano, Nigeria. Niger J Clin Pract 2017;20:479-83.

46. Deng X, Liu X, Fang R. Evaluation of the correlation between job stress and sleep quality in community nurses. Medicine (Baltimore) 2020;99:e18822.

47. Cash RE, Anderson SE, Lancaster KE, Lu B, Rivard MK, Camargo CA $\mathrm{Jr}$, Panchal AR. Comparing the prevalence of poor sleep and stress metrics in basic versus advanced life support emergency medical services personnel. Prehosp Emerg Care 2020;24:644-56.

48. Kwon DH, Hwang J, Cho YW, Song ML, Kim KT. The mental health and sleep quality of the medical staff at a hub-hospital against COVID-19 in South Korea. J Sleep Med 2020;17:93-7.

49. Wang S, Xie L, Xu Y, Yu S, Yao B, Xiang D. Sleep disturbances among medical workers during the outbreak of COVID-2019. Occup Med (Lond) 2020;70:364-9.

50. Şayık D, Açıkgöz A, Mutlu F. Sleep quality of medical staff during the Coronavirus Pandemic: a meta-analysis. J Turk Sleep Med 2021;8:1-6.

51. Wu K, Wei X. Analysis of psychological and sleep status and exercise rehabilitation of front-line clinical staff in the fight against COVID-19 in China. Med Sci Monit Basic Res 2020;26:e924085.

52. Şahin B, Hoşoğlu E, Önal BS. Anxiety symptoms in healthcare workers and their children during the COVID-19 pandemic in Turkey. Nam Kem Med J 2020;8:321-30. 